\title{
Діагностика психофізіологічного стану організму як одна з ключових проблем спортивної медицини
}

\author{
Удк 612.821.2 \\ 1Л. Г. Коробейнікова, ${ }^{1}$ Г. В. Коробейніков,
2 Ю. А. Радченко, ${ }^{3}$ Т. Г. Данько
}

${ }^{1}$ Національний університет фізичного виховання і спорту України, Київ, Україна 2Чорноморський державний університет імені Петра Могили, Миколаїв, Україна ${ }^{3}$ Національна академія служби безпеки України, Київ, Україна

\begin{abstract}
Резюме. Цель. Обоснование новейших путей диагностики психофизиологических состояний у спортсменов высокой квалификации.

Методы. Структура диагностики психофизиологического состояния спортсменов высокой квалификации состояло из трех основных блоков: исследование нейродинамических свойств нервной системы, ответственных за восприятие и переработку информации; исследование психоэмоциональных характеристик стрессостойкости к экстремальным условиям; оценка состояния вегетативной регуляции ритма сердца.

Результаты. Динамика функциональной подвижности нервных процессов в динамике учебнотренировочных сборов характеризуется изменением возможностей реагирования в сторону увеличения качества переработки информации с уменьшением скоростных характеристик и в конце цикла увеличения времени, т. е. ухудшением способности к восприятию и переработке информации. Характер реакции ритма сердца на ортостатическую нагрузку определяется степенью напряжения регуляторных систем организма. Выявлено, что у спортсменов с оптимальной реакцией и умеренным напряжением регуляции ритма обнаруживается преобладание низкочастотного спектра ритма сердца в условиях ортостатической нагрузки. Выводы. Предложенные алгоритмы диагностики психофизиологических состояний у спортсменов высокой квалификации показали свою эффективность и надежность на протяжении всего макроцикла подготовки Играм XXIX Олимпиады в Пекине и Играм XXX Олимпиады в Лондоне. Ключевые слова: психофизиологические состояния, спортсмены высокой квалификации, спортивная медицина, нейродинамических функции.
\end{abstract}

\begin{abstract}
Aim. Substantiation of the newest strategies of diagnosis of psychophysiological states of highly skilled athletes.

Methods. The structure of the diagnostics of psychophysiological state of highly skilled athletes consisted of three main units: the study of neural properties of the nervous system, responsible for perception and processing of information; the study of psycho-emotional characteristics of stress resistance to extreme conditions, assessment of autonomic regulation of the heart rhythm.

Results. Dynamics of functional mobility of nervous processes in the dynamics of training camps is characterized by a change in responsiveness towards increasing the quality of information processing with decreasing speed characteristics and, at the end of the cycle time increases, that is, the deterioration of the ability to perceive and process information. The character of the reaction of cardiac rhythm to orthostatic load was determined by the degree of tension of regulatory systems. Prevalence of low frequency cardiac rhythm was revealed in athletes with optimum response and moderate tension of rhythm regulation.

Conclusions. The elaborated algorithms of diagnostics of psychophysiological states in elite athletes showed the efficacy and reliability during the macrocycle of preparation for the XXIX Olympic Games in Beijing and XXX Olympic Games in London.
\end{abstract}

Keywords: psychophysiological state, athletes of high qualification, sports medicine, neurodynamic function. 
Постановка проблеми. Аналіз останніх досліджень та публікацій. Поняття про стан об'єкта або системи у фрізіології не $€$ новим питанням. Традиційно стан визначається як сукупність основних параметрів і характеристик будь-якого об'єкта, явища або процесу в певний момент (або інтервал) часу. Стан біологічної системи і зокрема організму людини можна класифрікувати за різними ознаками [2].

Відповідні стани характеризуються за такими рівнями: генетичний, морфологічний, фрізіологічний, психофрізіологічний, психічний, соціальнопсихологічний, соціальний [4]. Стани різних рівнів взаємозалежні, безліч станів і фаз розвитку людини організовано в єдності й цілісності особистості.

Визначення поняття «психофрізіологічний стан людини» $€$ досить складним, адже думки різних авторів грунтуються на різних рівнях фрункціонування людини. Деякі розглядають фрізіологічний рівень $[9,10]$, інші - психологічний $[5,18]$, а решта - обидва підходи разом [15].

Якщо розглядати стани організму людини як сукупність окремих елементів фрункціональних систем, можна зазначити, що у функціональному стані завжди присутні як психічна, так і фрізіологічна складові. Однак, оскільки багато психічних станів можуть бути тільки спостережуваними або тими, що вивчаються лише з використанням інтроспективного методу - за самооцінюванням самих осіб без залучення об'єктивних фрізіологічних методик, то створюється враження, що вони $\epsilon$ психологічними. І ця обставина надзвичайно ускладнює розробку об'єктивної класифрікації станів людини.

Поняття «стан» із загальнобіологічних позицій традиційно розглядається як певна сукупність процесів, які відбуваються в організмі людини, а також як ступінь розвитку та цілісності її біологічних структур.

Загальноприйнятим $€$ уявлення про стани, як про психічні явища, які відображають особливості фрункціонування нервової системи та психіки людини в певний період часу або адаптаційного процесу [13].

Коли йде мова про фрункціональні стани, то розуміють рівень функціонування людини в цілому або її окремих функціональних систем (сенсорної, інтелектуальної, моторної), а коли йдеться про психічні стани, то це якісна специфріка (модальність емоцій) реагування людини на ту або іншу ситуацію (без урахування рівня фрункціонування) [8]. Однак психічні стани складаються з різних рівнів, як якісних, так і кількісних характеристик, і тоді мова може йти про психофрізіологічні стани.
Діяльність людини та її результати зумовлюються не тільки стійкими індивідуальними характеристиками, але й значною мірою терміновими змінами, які виникають в організмі й визначають психофрізіологічні стани.

На нашу думку, психофізіологічний стан людини визначається фрункціональним станом психофрізіологічних функцій.

Психофрізіологічний стан $\epsilon$ відображенням способу забезпечення вищих психічних функцій, інтегральним вираженням яких $\epsilon$ усвідомлена, соціально детермінована, поведінкова та рухова діяльність, зокрема спортивна [12, 19].

Основою для реалізації вищих психічних функцій $\epsilon$ оптимальна діяльність, насамперед, центральної нервової системи. Поведінкова діяльність в цілому вимагає погодженої роботи аналізаторів рухового апарату та систем вегетативного забезпечення психофрізичних навантажень, включаючи активаційні процеси, що визначають характеристику психоемоційного фрону за будь-якої предметної діяльності.

Можна зазначити, що психофізіологічні стани пов'язані з психічними й фрізіологічними структурами організму людини. Таке визначення психофрізіологічного стану припускає, що це причинно-зумовлене явище, реакція не окремої системи або органа, а особистості в цілому із включенням як фрізіологічних, так і психічних рівнів (субсистем) керування та регулювання, що належать до підструктур і сторін особистості. Одночасно стан людини виражається не тільки в динаміці змін психофізіологічних показників, а також і у поведінкових реакціях.

У будь-якому психофрізіологічному стані повинні бути обов'язково представлені всі названі рівні і тільки у сукупності показників, що відображають кожний із цих рівнів, можна зробити висновок про наявний стан людини. Ні поведінка, ні різні психофрізіологічні показники, узяті окремо, не можуть вірогідно диференціювати один стан від іншого. Так само, як і зміна значень показників окремих фрізіологічних систем, може спостерігатися у різних станах організму.

Для успішного виступу у змаганнях спортсмену високої кваліфікації в сучасних умовах необхідно мати відповідний рівень основних фракторів підготовленості.

По-перше, рівень технічної майстерності. Технічна підготовленість обдарованого спортсмена відрізняється індивідуальними особливостями виконання рухових навичок, що надає перевагу над суперниками.

По-друге, оптимальний функціональний стан організму спортсмена. Основою забезпечення 
рухової діяльності у спорті $€$ функціональний стан у певному розумінні можливість мобілізації резервних можливостей організму.

По-третє, вироблена тактична стратегія. Спортсмен повинен мати чітке уявлення про суперників, план дії та набір алгоритмів поведінки в різних умовах змагальної діяльності.

Перелічені фактори мають обмеження досконалості. Адже зростання технічної майстерності залежить від спроможності нервової системи забезпечувати процес фрормування нових рухових навичок. Однак наявність домінантного центру на рівні кори головного мозку внаслідок інерційності обмежує цей процес [17]. Шляхи зростання фрункціональних можливостей спортсмена лімітуються резервами організму. Тактична стратегія залежить від багатьох чинників і також може бути обмежена.

Як відомо, психічні реакції, які виникають у спортсмена в умовах тренувальної і змагальної діяльності, обумовлені, насамперед, змінами психофрізіологічних функцій [13]. Тому доцільним $€$ визначати не лише психологічні, а й психофрізіологічні стани спортсменів.

Дослідження психофрізіологічних станів дає додаткову інформацію про загальний функціональний стан спортсмена:

- психофрізіологічні функції - це біологічне підґрунтя індивідуально-типологічних властивостей вищої нервової діяльності, що може бути використано при диференційній діагностиці функціонального стану організму людини;

- психофрізіологічні функції характеризують процес фоормвання і вдосконалення спеціальних навичок, що відображає стан фрункціональної системи організму, відповідальної за рівень технічної підготовленості спортсменів;

- внаслідок наявності стомлення у нервових центрах в умовах м'язової діяльності, фрункціональний стан психофрізіологічних фрункцій може бути чутливим індикатором розвитку втоми та перенапруження у спортсменів.

Отже, психофрізіологічний стан визначається динамікою психофрізіологічних функцій, емоційними реакціями і спрямованістю особистості спортсмена.

Роботу виконано згідно зі Зведеним планом НДР у сорері фрізичної культури і спорту на 2006-2010 рр. за темою 2.23 «Превентивні програми нейропсихофрізіологічної підтримки спортсменів високої кваліфікації на заключних етапах багаторічної підготовки» (номер держреєстрації 0109U007579).

Мета дослідження - обгрунтування новітніх шляхів діагностики психофрізіологічних станів у спортсменів високої кваліфікації.
Методи та організація дослідження. $\mathrm{Ha}$ етапі безпосередньої підготовки до Олімпійських ігор в Пекіні (2008) та Лондоні (2012), було розроблено систему комплексної діагностики психофрізіологічних станів організму спортсменів, членів національних команд України 3 грекоримської, вільної та жіночої боротьби з метою сприяння максимальної реалізації індивідуальних можливостей.

Структура діагностики психофрізіологічного стану спортсменів високої кваліфікації складалася $з$ трьох основних блоків:

- дослідження нейродинамічних властивостей нервової системи, відповідальних за сприйняття і переробку інфрормації;

- дослідження психоемоційних характеристик: стресостійкості до екстремальних умов;

- оцінка стану вегетативної регуляції ритму серця.

Традиційно до нейродинамічних функцій відносять характеристики сприйняття та переробки сенсорної інфрормації [11]. Враховуючи, що зоровий аналізатор у спорті, з одного боку, відіграє важливе значення при засвоєнні та відтворенні рухових навичок, з іншого - $є$ відображенням афрерентної частки інтегративної фрункціональної системи, відповідальної за ефективність діяльності.

Серед методів дослідження стану нейродинамічних функцій у спортсменів використовується оцінка балансу нервових процесів, латентного періоду зорово-моторної реакції та фрункціональної рухливості нервових процесів.

Для визначення врівноваженості процесів збудження та гальмування (балансу) у центральній нервовій системі було застосовано методику «реакція на рухомий об'єкт». Ця методика являла собою різновид складної сенсомоторної реакції, яка, крім сенсорного та моторного періодів, включала період відносно складної обробки сенсорного сигналу центральною нервовою системою. За результатами тестування визначалися показники: точність, стабільність, збуджуваність, тренд (за збудженням).

Використовувалась методика оцінки латентного періоду зорово-моторної реакції. Час реакції на зорові подразники складався з часу сприйняття, переробки та моторної реалізації на подразник. Завдання випробовуваного - реагувати на появу кожного сигналу (червоний прямокутник) натисканням на відповідну клавішу.

Для дослідження фрункціональної рухливості нервових процесів використовувалась методика оцінки максимального темпу обробки інформації за диференціюванням різних подразників. На 
ТАБЛИЦЯ 1 - Результати дослідження нейродинамічних функцій в динаміці навчально-тренувального збору у борців високої кваліфікації греко-римського стилю (медіана, верхній і нижній квартиль), $\mathrm{n}=\mathbf{4 0}$

\begin{tabular}{|c|c|c|c|}
\hline \multirow{2}{*}{ Показник } & \multicolumn{3}{|c|}{ Етап циклу навантажень } \\
\hline & початок & середина & кінець \\
\hline $\begin{array}{l}\text { Точність, } \\
\text { ум.од. }\end{array}$ & $\begin{array}{c}2,81 \\
2,17 ; 3,39 \\
\end{array}$ & $\begin{array}{c}2,31 \\
2,16 ; 2,71 \\
\end{array}$ & $\begin{array}{c}2,62 \\
2,17 ; 3,51 \\
\end{array}$ \\
\hline $\begin{array}{l}\text { Стабільність } \\
(\mathrm{cV}), \%\end{array}$ & $\begin{array}{c}2,99 \\
2,68 ; 3,30 \\
\end{array}$ & $\begin{array}{c}3,13 \\
2,30 ; 3,34 \\
\end{array}$ & $\begin{array}{c}3,13 \\
2,54 ; 3,53 \\
\end{array}$ \\
\hline $\begin{array}{l}\text { Збудження, } \\
\text { ум.од. }\end{array}$ & $\begin{array}{c}-0,02 \\
-1,95 ; 0,05 \\
\end{array}$ & $\begin{array}{c}-0,18 \\
-0,37 ; 0,35 \\
\end{array}$ & $\begin{array}{c}-0,36^{\star * *} \\
-2,16 ;-0,01 \\
\end{array}$ \\
\hline \multicolumn{4}{|c|}{ Латентний період зорово-моторної реакції } \\
\hline $\begin{array}{l}\text { Латентність, } \\
\text { мс }\end{array}$ & $\begin{array}{c}249,96 \\
245,32 ; 268,61 \\
\end{array}$ & $\begin{array}{c}260,09 \\
250,50 ; 271,64 \\
\end{array}$ & $\begin{array}{c}256,54 \\
246,13 ; 268,54 \\
\end{array}$ \\
\hline $\begin{array}{l}\text { Стабільність } \\
\text { реакції (cV), \% }\end{array}$ & $\begin{array}{c}14,95 \\
12,15 ; 17,88 \\
\end{array}$ & $\begin{array}{c}14,47 \\
10,98 ; 18,88 \\
\end{array}$ & $\begin{array}{c}14,08 \\
11,96 ; 17,37 \\
\end{array}$ \\
\hline \multicolumn{4}{|c|}{ Функціональна рухливість нервових процесів } \\
\hline $\begin{array}{l}\text { Динамічність, } \\
\text { \% }\end{array}$ & $\begin{array}{c}69,54 \\
62,01 ; 83,81 \\
\end{array}$ & $\begin{array}{c}69,88 \\
65,94 ; 88,18 \\
\end{array}$ & $\begin{array}{c}76,36 \\
66,72 ; 81,81 \\
\end{array}$ \\
\hline $\begin{array}{l}\text { Пропускна } \\
\text { здатність, } \\
\text { ум.од. }\end{array}$ & $\begin{array}{c}1,849 \\
1,61 ; 1,93\end{array}$ & $\begin{array}{c}1,94 \\
1,58 ; 2,04\end{array}$ & $\begin{array}{c}1,95 \\
1,67 ; 2,08\end{array}$ \\
\hline $\begin{array}{l}\text { Граничний } \\
\text { час переробки } \\
\text { інформації, мс }\end{array}$ & $\begin{array}{c}320,13 \\
290,34 ; 350,62\end{array}$ & $\begin{array}{c}290,73^{*} \\
290,16 ; 440,39\end{array}$ & $\begin{array}{c}320,16^{* *} \\
290,62 ; 410,63\end{array}$ \\
\hline $\begin{array}{l}\text { Імпульсив- } \\
\text { ність-реф- } \\
\text { лективність, } \\
\text { ум.од. }\end{array}$ & $\begin{array}{c}0,16 \\
-0,09 ; 0,29\end{array}$ & $\begin{array}{c}0,05^{*} \\
-0,19 ; 0,08\end{array}$ & $\begin{array}{c}0,03^{*} \\
-0,03 ; 0,17\end{array}$ \\
\hline
\end{tabular}

Примітки: відмінності достовірні при * $p<0,05$, порівняно із початком навчально-тренувального збору; ${ }^{*} p<0,05$, порівняно із серединою навчально-тренувального збору.

екрані монітора відображалося стилізоване зображення світлофора, на якому по черзі у випадковому порядку висвічувалися червоне, жовте і зелене світло. Завдання випробуваного - в максимальному темпі у відповідь на появу червоного сигналу натискати праву клавішу, на появу зеленого - ліву, а на появу жовтого - пропускати натискання. За допомогою тесту визначалися показники: динамічність, пропускна здатність, гранична швидкість переробки інформації, імпульсивність.

Рівень психоемоційної стійкості (стресостійкості) спортсменів визначали за результатами «Стрес-тесту» на основі переробки інформації при позиційному виборі об'єктів на екрані дисплею у відповідних клітинах, за певного ліміту часу, для здійснення такої кількості подразників, що моделювало стан психоемоційного інфрормаційного навантаження. За результатами тестування визначали такі показники, як стресостійкість, пропускна здатність та імпульсивність.

Всі перераховані методики входять до складу апаратно-програмного психодіагностичного комплексу «Мультипсихометр-05».
Вегетативна регуляція оцінювалася за показниками статистичного аналізу варіабельності ритму серця. Для цієї мети використовувався кардіомонітор «Polar RS800CX». Реєструвалися параметри вегетативної регуляції ритму серця та результати спектрального аналізу у спортсменів. Отримані дані було представлено у протоколі за допомогою статистичної програми «KubiosHRV».

Статистичний аналіз проводився за допомогою програмного пакету Statgraphics 5.1 (Manugistics, Inc.). У зв'язку із тим що обстежувана вибірка не підлягала нормальному розподілу за показниками, які вивчалися, було застосовано методи непараметричної статистики за допомогою критерію знакових рангових сум Вілкоксона. Для демонстрації розподілу даних використовувався інтерквартильний розмах, вказуючи першу квартиль (25 \% персентиль) та третю квартиль (75 \%) [14].

Результати досліджень та їх обговорення. Для вивчення особливостей прояву нейродинамічних фрункцій було проведено дослідження динаміки навчально-тренувальних зборів у 40 борців високої кваліфікації греко-римського стилю. Дослідження проводилося на початку, в середині та наприкінці навчально-тренувального збору.

У таблиці 1 представлено результати дослідження нейродинамічних фрункцій у динаміці навчально-тренувального збору у борців грекоримського стилю високої кваліфрікації.

Аналіз результатів дослідження виявив наявність балансу нервових процесів у елітних атлетів на початку, в середині та наприкінці циклу тренувальних навантажень. Достовірне зростання зі зворотним значенням показника збудження в динаміці тренувальних навантажень, вказує на тенденцію зрушення балансу нервових процесів у бік гальмування.

Можна зазначити, що у процесі тренувального циклу у спортсменів, психоемоційне стомлення призводить до зрушення балансу нервових процесів у бік переважання процесу гальмування.

Аналіз результатів дослідження латентного періоду зорово-моторної реакції свідчить про відсутність достовірної різниці за показниками латентності та стабільності реакцій, в умовах тренувальних навантажень, у осіб із високим рівнем функціональної підготовленості.

Однак у середині та наприкінці навчальнотренувального збору виявляється тенденція до зростання латентного періоду простої зоровомоторної реакції у елітних атлетів. Ця обставина вказує на тенденцію до погіршення швидкості переробки інформації.

За результатами дослідження фрункціональної рухливості нервових процесів спостерігається 
ТАБЛИЦЯ 2 - Результати дослідження стресостійкості у спортсменів у борців високої кваліфікації греко-римського стилю в різних вікових групах, $\mathrm{n}=19$

\begin{tabular}{|c|c|c|c|c|c|c|}
\hline \multirow{3}{*}{ Показник } & \multicolumn{3}{|c|}{ Перша вікова група, n = 12} & \multicolumn{3}{|c|}{ Друга вікова група, n = 7} \\
\hline & \multirow{2}{*}{ Медіана } & \multicolumn{2}{|c|}{ Квартиль } & \multirow{2}{*}{ Медіана } & \multicolumn{2}{|c|}{ Квартиль } \\
\hline & & нижній & верхній & & нижній & верхній \\
\hline Стресостійкість, ум.од. & 88,27 & 79,01 & 90,33 & $109,20^{*}$ & 102,83 & 118,35 \\
\hline Загальна ефективність, ум.од. & 1,09 & 1,07 & 1,13 & 1,10 & 0,92 & 1,15 \\
\hline Імпульсивність, ум.од. & $-0,04$ & $-0,06$ & 0,00 & $-0,03$ & $-0,06$ & 0,00 \\
\hline
\end{tabular}

* Відмінності достовірні при р < 0,05, порівняно із першою віковою групою спортсменів.

достовірне зменшення показника граничного часу переробки інфоормації в середині тренувального збору, спортсменів високої кваліфрікації, порівняно із початком. Отриманий результат вказує на покращення здатності до сприйняття та переробки інформації у спортсменів, в середині тренувального циклу (див. табл. 1). Крім того, за показником імпульсивність-рефлективність спостерігається зниження абсолютних значень в динаміці циклу тренувальних навантажень.

Показник імпульсивності у тесті «Функціональна рухливість нервових процесів» відображає домінуючу тенденцію до генерування всіх сенсорних реакцій (в тому числі спонтанних) на подразники в процесі виконання тесту. Показник рефрлективності відображає імовірність виникнення саме значимих реакцій на зорові подразники. Виявлена динаміка показників імпульсивності рефлективності вказує на зміщення можливостей реагування у бік зниження швидкості (імпульсивності) та покращення якості реагування (рефлективності).

Таким чином, динаміка функціональної рухливості нервових процесів в динаміці навчальнотренувальних зборів характеризується зміною можливостей реагування у бік зростання якості переробки інформації зі зменшенням швидкісних характеристик та в кінці циклу збільшення часу, тобто погіршенням здатності до сприйняття та переробки інсрормації.

Аналіз стресостійкості дає можливість виявити спроможність протистояти психоемоційним навантаженням, які супроводжують зокрема змагальну діяльність спортсменів.

Для вивчення особливостей стресостійкості було досліджено 19 борців, членів національної збірної України боротьби з греко-римської. Всіх досліджених було диференційовано на дві групи: перша група - 12 спортсменів віком 19-24 років, друга - 7 спортсменів віком 27-31 рік. В таблиці 2 представлено значення показників стресостійкості у спортсменів різних вікових груп.

За даними таблиці 2, достовірних відмінностей між показниками загальної інтенсивності та імпульсивності у різних вікових групах не виявлено. Проте за показником стресостійкості мають прояв достовірні відмінності серед спортсменів різних вікових груп. Стресостійкість визначається за співвідношенням середньої пропускної здатності зорового аналізатора на початку тесту та пропускної здатності наприкінці тесту. Іншими словами, показник стресостійкості вказує на можливість утримання достатнього рівня пропускної здатності зорової сенсорної системи в умовах психоемоційних навантажень. 3 огляду на це, кращий показник стресостійкості виявляється у спортсменів старшої вікової групи, порівняно із молодшою віковою групою.

Однією з ключових компонентів психофізіологічного стану спортсмена в умовах напруженої м'язової діяльності $\epsilon$ система вегетативної регуляції ритму серця. Існує багато різних підходів щодо виявлення характеру реагування системи регуляції кардіоінтервалів на відповідні навантаження $[1,3]$. Однак в умовах поточного контролю за станом спортсмена найбільш поширеним залишаються тести із навантаженнями зокрема 3 ортостатичним [6].

3 метою виявлення відповідних функціональних станів було проведено ортостатичну пробу серед 29 спортсменів високої кваліфікації, членів збірної команди України з боротьби греко-римської.

За попереднім аналізом системи варіабельності ритму серця було визначено та запропоновано шкалу, за якою був зроблений розподіл відповідних реакцій.
Тип реакції регуляції ритму серця

Оптимальна

Помірне напруження

Перенапруження
Середнє квадратичне відхилення R-R-інтервалів, c

$$
\begin{gathered}
\geq 0,075 \\
0,053 \\
\leq 0,022
\end{gathered}
$$

Основним критерієм, покладеним у відповідну класифрікацію реакцій регуляції ритму, було визначено середнє квадратичне відхилення R-Rінтервалів. За даними ряду авторів, середнє квадратичне відхилення R-R-інтервалів відображає 
ТАБЛИЦЯ 3 - Значення параметрів вегетативної регуляції ритму серця у спортсменів з різною реакцією на ортостатичне навантаження (медіана, верхній і нижній квартиль), $\mathrm{n}=29$

\begin{tabular}{|c|c|c|c|c|}
\hline \multirow[b]{2}{*}{ Показник } & \multirow{2}{*}{$\begin{array}{c}\text { Положення } \\
\text { тіла }\end{array}$} & \multicolumn{3}{|c|}{ Тип реакції регуляції ритму серця } \\
\hline & & оптимальний & $\begin{array}{l}\text { помірне } \\
\text { напруження }\end{array}$ & $\begin{array}{c}\text { пере- } \\
\text { напруження }\end{array}$ \\
\hline \multirow[t]{2}{*}{ Середня тривалість R-R-інтервалів, с } & Горизонтальне & $\begin{array}{l}0,92 \\
0,89 ; 1,130\end{array}$ & $\begin{array}{l}0,91 \\
0,800 ; 0,95\end{array}$ & $\begin{array}{l}0,75^{\star *} \\
0,61 ; 0,89\end{array}$ \\
\hline & Вертикальне & $\begin{array}{l}0,79 \\
0,72 ; 0,84 \\
\end{array}$ & $\begin{array}{l}0,72 \\
0,64 ; 0,86 \\
\end{array}$ & $\begin{array}{l}0,69^{*} \\
0,62 ; 0,90 \\
\end{array}$ \\
\hline \multirow[t]{2}{*}{ Середнє квадратичне відхилення R-R-інтервалів, с } & Горизонтальне & $\begin{array}{l}0,070 \\
0,063 ; 0,074\end{array}$ & $\begin{array}{l}0,058^{*} \\
0,041 ; 0,084\end{array}$ & $\begin{array}{l}0,030^{* *} \\
0,022 ; 0,048\end{array}$ \\
\hline & Вертикальне & $\begin{array}{l}0,05 \\
0,05 ; 0,07\end{array}$ & $\begin{array}{l}0,04 \\
0,02 ; 0,05\end{array}$ & $\begin{array}{l}0,02^{*} \\
0,02 ; 0,04\end{array}$ \\
\hline
\end{tabular}

Примітки: відмінності достовірні при * $>$ < 0,05, порівняно із групою спортсменів з оптимальною реакцією регуляції ритму серця; ${ }^{*} p<0,05$, порівняно із групою спортсменів реакцією з помірним напруженням регуляції ритму серця.

ступінь напруження регуляції ритму серця, як сумарного впливу обох відділів вегетативної регуляції на пазухо-передсердний вузол серця [16].

Дослідження виявили, що $34 \%$ спортсменів мали оптимальний тип реакції ритму серця на ортостатичне навантаження, 52 \% спортсменів - помірне напруження регуляції ритму серця, 14 \% - перенапруження регуляції ритму серця.

Проведений аналіз статистичних параметрів кардіоінтервалів свідчить, що характер реакції ритму серця на ортостатичне навантаження визначається ступенем напруження регуляторних систем (табл. 3).

За даними спектрального аналізу виявлено переважання наднизькочастотного спектра ритму серця у осіб з оптимальною реакцією та помірним напруженням на ортостатичне навантаження. Цей фракт вказує на більшу активацію симпатичного тонусу вегетативної нервової системи (табл. 4).

В осіб з реакцією перенапруження на ортостатичне навантаження виявляється переважання наднизькочастотних компонентів за рахунок симпатичного впливу на пазухо-передсердний вузол серця (див. табл. 4). Цей фракт відображає вплив центральних механізмів енергометаболічного обміну у горизонтальному стані.

У вертикальному стані виявлено переважання низькочастотного спектра ритму серця у осіб з оптимальною реакцією та помірним напруженням на ортостатичне навантаження. Однак у цих

ТАБЛИЦЯ 4 - Значення параметрів спектрального аналізу серцевого ритму у спортсменів з різною реакцією на ортостатичне навантаження (медіана, верхній i нижній квартиль), $\mathbf{n}=29$

\begin{tabular}{|c|c|c|c|c|}
\hline \multirow[b]{2}{*}{ Показник } & \multirow{2}{*}{$\begin{array}{c}\text { Положення } \\
\text { тіла }\end{array}$} & \multicolumn{3}{|c|}{ Тип реакції регуляції ритму серця } \\
\hline & & оптимальний & $\begin{array}{c}\text { помірне } \\
\text { напруження }\end{array}$ & $\begin{array}{c}\text { пере- } \\
\text { напруження }\end{array}$ \\
\hline \multirow[t]{2}{*}{ Наднизькочастотний спектр, мc ${ }^{2}$ (VLF) } & Горизонтальне & \begin{tabular}{|l}
22,00 \\
5,$00 ; 37,00$
\end{tabular} & $\begin{array}{l}8,00^{*} \\
3,00 ; 21,00\end{array}$ & $\begin{array}{l}8,00^{*} \\
1,00 ; 16,50\end{array}$ \\
\hline & Вертикальне & $\begin{array}{l}4,00 \\
1,00 ; 13,00\end{array}$ & $\begin{array}{l}1,00^{*} \\
2,00 ; 22,00\end{array}$ & $\begin{array}{l}0,50^{*} \\
2,00 ; 3,00\end{array}$ \\
\hline \multirow[t]{2}{*}{ Низькочастотний спектр, мc² (LF) } & Горизонтальне & \begin{tabular}{|l|}
43,50 \\
14,$00 ; 62,00$ \\
\end{tabular} & \begin{tabular}{|l|}
$13,00^{*}$ \\
9,$00 ; 34,00$ \\
\end{tabular} & $\begin{array}{l}4,00^{* *} \\
2,50 ; 19,50\end{array}$ \\
\hline & Вертикальне & $\begin{array}{l}9,00 \\
2,00 ; 12,00\end{array}$ & $\begin{array}{l}9,00 \\
2,00 ; 41,00\end{array}$ & $\begin{array}{l}1,50^{* *} \\
1,00 ; 12,00\end{array}$ \\
\hline \multirow[t]{2}{*}{ Високочастотний спектр, мс ${ }^{2}$ (HF) } & Горизонтальне & \begin{tabular}{|l|}
35,00 \\
31,$00 ; 52,00$
\end{tabular} & $\begin{array}{l}7,00^{*} \\
3,00 ; 17,00\end{array}$ & $\begin{array}{l}2,00^{* *} \\
0,50 ; 7,50\end{array}$ \\
\hline & Вертикальне & $\begin{array}{l}2,50 \\
2,00 ; 3,00\end{array}$ & $\begin{array}{l}1,00 \\
1,00 ; 5,00\end{array}$ & $\begin{array}{l}1,00 \\
1,00 ; 3,50\end{array}$ \\
\hline \multirow[t]{2}{*}{ Відношення LF/HF } & Горизонтальне & \begin{tabular}{|l|}
1,08 \\
0,$71 ; 1,34$ \\
\end{tabular} & \begin{tabular}{|l|}
2,04 \\
1,$03 ; 2,77$ \\
\end{tabular} & \begin{tabular}{|l|}
$4,28^{*}$ \\
2,$10 ; 8,73$ \\
\end{tabular} \\
\hline & Вертикальне & $\begin{array}{l}3,87 \\
1,27 ; 5,46\end{array}$ & $\begin{array}{l}5,43^{*} \\
2,56 ; 9,83\end{array}$ & $\begin{array}{l}3,35^{* *} \\
2,74 ; 5,64\end{array}$ \\
\hline
\end{tabular}

Примітки: відмінності достовірні при * $<$ 0,05, порівняно із групою спортсменів з оптимальною реакцією регуляції ритму серця; ${ }^{* *} p<0,05$, порівняно із групою спортсменів реакцією з помірним напруженням регуляції ритму серця. 
спортсменів простежується зростання щільності високочастотного спектра потужності ритму серця. Цей фракт вказує на активацію парасимпатичного тонусу вегетативної нервової системи (див. табл. 4).

У осіб з реакцією перенапруження на ортостатичне навантаження виявляється переважання низькочастотних компонентів за рахунок симпатичного впливу на пазухо-передсердний вузол серця (див. табл. 4).

Таким чином, характер реакції ритму серця на ортостатичне навантаження визначається ступенем напруження регуляторних систем організму. Виявлено, що у спортсменів із оптимальною реакцією та помірним напруженням регуляції ритму виявляється переважання низькочастотного спектра ритму серця в умовах ортостатичного навантаження.

\section{Висновки:}

1. Динаміка психофрізіологічних показників у процесі навчально-тренувальних зборів характеризується зростанням можливостей сприйняття при переробці інорормації зі зменшенням швидкісних характеристик у середині циклу, збільшенням часу, тобто погіршенням здатності до сприйняття та переробки інорормації - наприкінці циклу, що свідчить про оптимальний тип реагування на навантаження при підготовці до

\section{Література}

1. БаеВский Р. М. Проблема оценки адаптационных возможностей человека в авиакосмической фризиологии / Р. М. Баевский, Е. Ю. Берсенев, О.И.Орлов и др. // Рос. фиизиол. журн. - 2012. - № 1. - С. 95-107.

2. Дуров А. М. Оценка уровня функциональных возможностей и биологического возраста спортсменов : (хронобиологические аспекты) / А. М. Дуров, Т. В. Аминева, В. А. Терехин, Ю. А. Румянцева // Теория и практика физ. культуры. - 2005. - № 8. - С. 24-26.

3. Лях Ю. $Є$. Кількісна оцінка психофрізіологічного стану людини за успішністю виконаної роботи / Ю. Є. Лях, А. М. Черняк, В. Г. Гур'янов, Ю. Г. Вихованец // Фізіол. журн. 2001. - Т. 27, № 6. - С. 63-70.

4. Лизогуб В. С. Індивідуальні психофізіологічні особливості людини та професійна діяльність / В. С. Лизогуб // Фізіол. журн. 2010. - № 2. - С. 34-42.

5. Ильин Е. П. Психофизиология состояний человека / Е. П. Ильин. - СПб.: Питер, 2005. - 412 с.

6. Хекалов Е. М. Неблагоприятные психические состояния спортсменов, их диагностика и регуляція: учеб. пособ. / Е. М. Хекалов. - 2-е изд. - М.: Сов. спорт, 2003. - 64 с.

7. РоженцоВ В. В. Диагностика предстартового функционального состояния организма спортсменов на основе психофризиологических параметров ЦНС / В.В.Роженцов, Н. И. Палагина, М. М. Полевщиков // Вестн. спорт. науки. - 2009. - № 3. - С. 39-44.

8. Наймушина А. Г. Психофизиологические механизмы экологической адаптации / А. Г. Наймушина // Фундамент. исслед. - 2010. - № 6 - С. 76-81. важливих змагань року та для досягнення фрази суперкомпенсації у передстартовому стані.

2. Стресостійкість як критерій успішності в спорті вищих досягнень зростає з віком. Припускаємо, що можливо це прояв компенсаторних механізмів адаптації, а можливо тільки борці з високим рівнем стресостійкості залишаються у спорті на довше.

3. Характер реакції ритму серця на ортостатичне навантаження визначається ступенем напруження регуляторних систем організму. Виявлено, що у спортсменів із оптимальною реакцією та помірним напруженням регуляції ритму виявляється переважання наднизькочастотного спектра ритму серця в умовах ортостатичного навантаження, що свідчить про активацію симпатичного відділу.

4. Запропоновані алгоритми діагностики психофрізіологічних станів у спортсменів високої кваліфікації показали свою ефективність та надійність протягом всього макроциклу підготовки до Ігор XXIX Олімпіади в Пекіні та Ігор XXX Олімпіади в Лондоні.

Перспективи подальших досліджень будуть спрямовані на пошук інших інформативних психофрізіологічних критеріїв фрункціонального стану спортсменів високої кваліфікації при підготовці до основних змагань року.

\section{References}

1. Bayevsky R. M. Problem of adaptation performance of human in aero-space physiology / R. M. Baevskiy, E. U Bersenev, O. I. Orlov, I. B. Ushakov, A. G. Chernikova // Rus. fiziologichesky zhurnal. -2012 . - N 1. - P. 95-107.

2. Durov A. M. Assessment of level of functional performance and biological age of athletes: (chrono-biological aspects) / Durov A. M., Amineva T. V., Terehin V. A., Rumiantseva U. A. // Teoriya i praktika fizkultury. - 2005. N 8. - P. 24-26.

3. Liakh U. E. Quantification assessment of psychophysiological states for efficiency of work / U. E. Liakh, A. M. Cherniak, V. G. Gurianov, U. G. Vikhovanets // Fiziologichesky zhurnal. - 2001. - Vol. 27, N 6. - P. 63-70.

4. Lizogub V. S. Individual psychophysiological peculiarities of human and professional activity / V. S. Lizogub // Fiziologichesky zhurnal. - 2010. - N 2. - P. 34-42.

5. Ilyin E. P. Psychophysiology of human states / E. P. Ilyin - Saint Petersburg: Piter, 2005. - 412 p. 6.

6. Khekalov E. M. Adverse psychical states of athletes, diagnostics and regulation: Textbook / E. M. Khekalov. 2-edit. - Moscow: Sov. sport, 2003. - 64 p.

7. Rozhentsov V. V. Diagnostic of prestart functional states of organism of athletes on the basic of psychophysiological parameters of CNS / V. V. Rozhentsov , N. I. Palagina, M. M. Polevshikov // Vesnik sport. nauki. - 2009. - N 3. P. 39-44.

8. Naimushina A. G. Psychophysiological mechanisms of ecology adaptation / A. G. Naimushina // Fundamental study. -2010 . - N 6 - P. 76-81. 
9. КоробейнікоВа Л. Г. Детермінанта психофізіологічного стану у спортсменів високої кваліфікації з різними емоційними характеристиками / Л. Г. Коробейнікова // Педагогіка психологія та мед.-біол. пробл. фріз. виховання і спорту. - Х.: ХНУ, 2011.- № 4.- С. 94-98.

10. Цимбалюк Ж. А. Влияние подвижности нервной системы на способности спортсмена / Ж. А. Цимбалюк // Педагогіка, психологія та мед.-біол. пробл. фріз. виховання і спорту. - Х.: ХДАДМ, 1998. - № 5.- С. 18-20.

11. Макаренко М. В. Нейродинамічні властивості спортсменів різної кваліфікації та спеціалізації / М. В. Макаренко, В. С. Лизогуб, О. П. Безкопильний / /Актуальні проблеми фрізичної культури і спорту: зб. наук. пр. - К.: ДНДІФКС, 2004. - № 4. - С. 105-110.

12. Ухтомский $A$. А. Доминанта кака фрактор поведения / А. А. Ухтомский // Журн. практик. психолога. 2005.- T. 11. - С. 9-38.

13. КоробейнікоВ Г. В. Діагностика психоемоційних станів у спортсменів / Г. В. Коробейніков, О. К. Дуднік // Спорт. медицина. - К.: Олімп. л-ра, 2006. - №1. - С. 33-36.

14. Макаренко Н. В. Формирование свойств нейродинамических функций у спортсменов / Н. Макаренко, В. Лизогуб, А. Безкопыльный //Наука в олимп. спорте. 2005. - № 2. - С. 80-86.

15. Реброва О. Ю. Описание процедуры и результатов статистического анализа медицинских данных в научных публикациях / О. Ю. Реброва / / Междунар. журн. мед. практики. - 2000. - № 4. - С. 43-46.

16. Aubert A. E. Heart rate variability in athletes / A. E. Aubert, B. Steps, F. Becker // Sports Med. - 2003. № 33 (12). - P. 889-919.

17. Balocchi R. Revisting the potentials of time-domain indexes in the short-term HRV analysis / R. Balocchi, F. Cantini, M. Vranini // Amer. J. Cardilogy. - 2003. № 14. - P. 263-267.

18. КоВаленко С. О. Аналіз варіабельності серцевого ритму за допомогою методу медіанної спектрограми / С. О. Коваленко // Фізіол. журн. - 2005. - Т. 51, № 3. C. 92-95.

19. Tulppo M. P. Effect of exersice and passive headup tilt on fractal and complexity properties of heart rate dynamics / M. P.Tulppo, R. L. Haghson, T. H. Makikallio // Amer. J. Physiology Heart Circ. Physiology. - 2001. № 280(3). - P. 1082-1087.

george.65@mail.ru

lesia.65@mail.ru

yuri_radchenko@ukr.net

academy@ssu.gov.ua
9. Korobeynikova L. G. Determinant of psychophysiological states in athletes of high qualification with different emotions characteristics // L. G. Korobeynikova / Pedagogics, psychology, medical-biological problem of physical training and sport. - Kharkiv: KNU, 2011. - N 4.- P. 94-98.

10. Tsimbaliuk J. A. Influence of mobility of nervous system on abilities of athletes / J. A. Tsimbaliuk / / Pedagogics, psychology, medical-biological problem of physical training and sport. - Kharkiv: KNU, 1998. - N 5. - P. 18-20.

11. Makarenko M. V. Neurodynamics of properties of athletes of different qualification and specialization / M. V. Makarenko, V. S. Lizogub, O. P. Bezkopilniy //Aktualny problemy fizkultury i sportu: Edit., N 4. - Kiev: DNDIFKS, 2004. - P. 105-110.

12. Ukhtomskiy A. A. Dominant as factor of behaviors / A. A. Ukhtomskiy // Journal of practical psychology 2005. Vol. 11, - P. 9-38.

13. Korobeynikov G. V. Diagnostics of psycho-emotion states in athletes / G. V. Korobeynikov, O. K. Didnik // Sport. meditsina. - Kiev: Olimpiyskaya literatura, 2006. N 1. - P. 33-36.

14. Makarenko N. V. Forming of properties of neurodynamics functions in athletes / N. Makarenko, V. Lizogub, A. Beskopilniy //Nauka v Olimpiyskom sporte. - 2005. N 2. - P. $80-86$.

15. Rebrova $O$. U. Description of the procedure and the results of statistical analysis of medical data in scientific publications / O. U. Rebrova // International journal of medicine practice. -2000 . - N 4. - P. 43-46.

16. Aubert A. E. Heart rate variability in athletes / A. E. Aubert, B. Steps, F. Becker // Sports Medicine. 2003. - N 33 (12). - P. 889-919.

17. Balocchi R. Revisting the potentials of time-domain indexes in the short-term HRV analysis / R. Balocchi, F. Cantini, M. Vranini // American Journal Cardiology. - 2003. N 14. - P. 263-267.

18. Kovalenko S. O. Analysis of variability of heart rate for help of median spectrogram / S. O. Kovalenko // Fiziologichesky zhurnal. - 2005. - Vol. 51. - N 3. - P. 92-95.

19. Tulppo M. P. Effect of exersice and passive head-up tilt on fractal and complexity properties of heart rate dynamics / M. P.Tulppo, R. L. Haghson, T. H. Makikallio // American Journal Physiology Heart Circ. Physiology. - 2001. N 280(3). - P. 1082-1087.

Надійшла 16.09.2015 